\title{
Industry and Entrepreneurship component of the Murmansk region construction complex strategic chart
}

\author{
Aleksandr Kozlov $^{1,2 *}$, Svetlana Gutman ${ }^{1}$, and Ekaterina Tereshko ${ }^{1}$ \\ ${ }^{1}$ Peter the Great St. Petersburg Polytechnic University, Polytechnicheskaya, 29, St. Petersburg, \\ 195251, Russia \\ ${ }^{2}$ Luzin Institute for Economic Studies of the Federal Research Centre «Kola Science Centre of the \\ Russian Academy of Sciences», ul.Fersmana, 24a, Apatity, 184209, Russia
}

\begin{abstract}
A key condition for the sustainable development of the Russian Federation Arctic Zone (RFAZ) territories is a well-developed infrastructure of the region. By the term "infrastructure of the region", it is common to mean the whole set of functional systems that ensure the vital activity and competitiveness of the region. One of basic elements of the infrastructure is the region's construction complex, which includes housing construction (low-rise and high-rise), industrial construction, social construction, cultural construction, road construction, and general construction. This study explores the strategic development of the construction complex of the Murmansk region as one of the RFAZ territories. Strategic development of the regional construction complex is provided by construction companies and organizations. The analysis of construction enterprises and organizations activity showed that the construction complex development depends strongly on economic crises. In this regard, the list of actions that allow providing balanced development for the regional construction complex has been offered. Based on the identified activities, benchmarks were identified, and the "Industry and Entrepreneurship" component of the strategic chart for the Murmansk region construction complex was developed.
\end{abstract}

\section{Introduction}

The construction complex provides the region with a multi-level infrastructure, including industrial facilities (buildings and structures for industrial purposes, security objects), nonindustrial facilities (residential buildings, utility facilities, social services, cultural places), and linear facilities (roads, bridges, vehicular traffic tunnels). Subsequently, by attaining the high level of the regional construction complex development it is possible to increase the region's competitiveness regarding both other Russian regions and foreign countries territories.

According to the Strategy for the Development of the Arctic Zone of the Russian Federation and the Provision of National Security up to 2020, the construction complex

*Corresponding author: avk55-spb@yandex.ru 
development should be considered a relevant issue [1] regarding the RFAZ territories in general and in the Murmansk region [2] in particular. It is worth paying attention to the Murmansk region location, as it represents an example of a coastal Arctic-oriented region [3]. In this regard, it is necessary to determine features that distinguish the coastal region from the inland ones [4]: 1) the marine transport availability in the sectorial composition of economy; 2) industrial fishery development; 3) coastal infrastructure substantial contribution to the regional development. Furthermore, according to the Murmansk region socioeconomic development analysis conducted by Skufyina T.P. and others [5], the region possesses the most well-balanced and diversified economy structure among RFAZ territories. Therefore, it is necessary to develop the infrastructure of the Murmansk region maritime territories for it is supposed to provide socioeconomic development of the region. The problem of RFAZ development has been considered in a variety of studies, including those provided by the following authors: Skufina TP, Toropushina E.E., Baranov S.V., Sorokina N.Yu., Tsygankova A.A., Romanchenko OV, Shemetkova O.L. ., Pozmogova S. B., Miroshnichenko S. V., Vorobyov V. S., Kamenetsky M. I., Belousova L. S., Baburin V. L., Zemtsov S. P., Alekseeva T.R.

In their studies [5-7], authors conducted an analysis of RFAZ cohesive socioeconomic development emphasizing general infrastructure development. Thus, Tsygankova A.A. and others in their study [6] explore current RFAZ infrastructure condition be means of assessing priority development projects and their viability. The authors of the study [7] consider the municipal settlements system evolution and the dynamic of RFAZ socioeconomic development.

Studies considering RFAZ land invasion with the construction complex development held as a core issue are also of great importance. The study [8] determines possibilities of construction complex participation in RFAZ land invasion. Sorokina N.U. [4] in her paper explores Russian inshore territories including RFAZ territories and determines their socioeconomic relevance by means of index method. In the paper [9] the author uses the example of Russia to explore the construction complex innovative development, assesses the construction complex innovative potential and determines factors facilitating the construction complex technology transfer.

Some of the studies [10-12] are dedicated to the Russian Federation regional construction complex development and management. In their study, Pozmogova S.B. and Belousova L.S. consider modern mechanism of the regional construction complex management introducing cluster policy as an instrument for regional construction complex development. Miroshnichenko S.V. and Vorobiev V.S. in their study [12] put forward means for regional construction complex competitiveness improvement by means of comprehensive approach.

The results of the scientific sources analysis acknowledge both the importance of regional construction complex development and the necessity of establishing a strategic management tool to achieve the next level of RFAZ socioeconomic development. It is necessary to provide accordance between regional strategic goals and Murmansk Region construction complex development policy. This can be implemented by means of regional indicators complex (RIC) suggested by the authors in the paper [14], basing on strategic charts development.

Therefore, the objective of the current paper is to develop a component of the RIC "Industry and Entrepreneurship" based on the analysis of the Murmansk region construction complex business environment. In accordance with the objective determined above, it is necessary to fulfil the following tasks:

1) to analyse civil engineering organizations and enterprises of the Murmansk region;

2) to identify activities that ensure the development of the regional construction complex;

3) to develop the "Industry and Entrepreneurship" RIC component.

The object of the research is the Murmansk region, and the subject of the research is the construction complex. 


\section{Research methodology}

Methodological framework of the study is represented by both quantitative and qualitative methods. Quantitative methods include collection, processing and analysis of socioeconomic indicators of state statistics concerning line of business "Construction" for the territories of the Russian Federation. The analysis is carried out by means of the following indicators: the number of existing construction companies and organizations (units); scope of work performed by the type of economic activity "Construction" (million rubles); number of buildings (units); total area of buildings (thousand $\mathrm{m}^{2}$ ). Qualitative methods imply the usage of the RIC methodology for developing the "Industry and Entrepreneurship" component.

\section{Results and discussion}

While researching the Murmansk region construction complex, it is necessary to analyse all the organizations and enterprises operating in the region and having "Construction" as a type of economic activity. By 2016, there are 1785 such organisations, including 1230 small enterprises.

First, we should evaluate the number of construction enterprises and the amount of work performed on the line of business "Construction" in the Murmansk region during the period of 14 years from 2003 to 2016 . The graph in the fig. 1 is based on the state statistics quantitative data [15] and reflects the activities of regional construction enterprises and organizations.

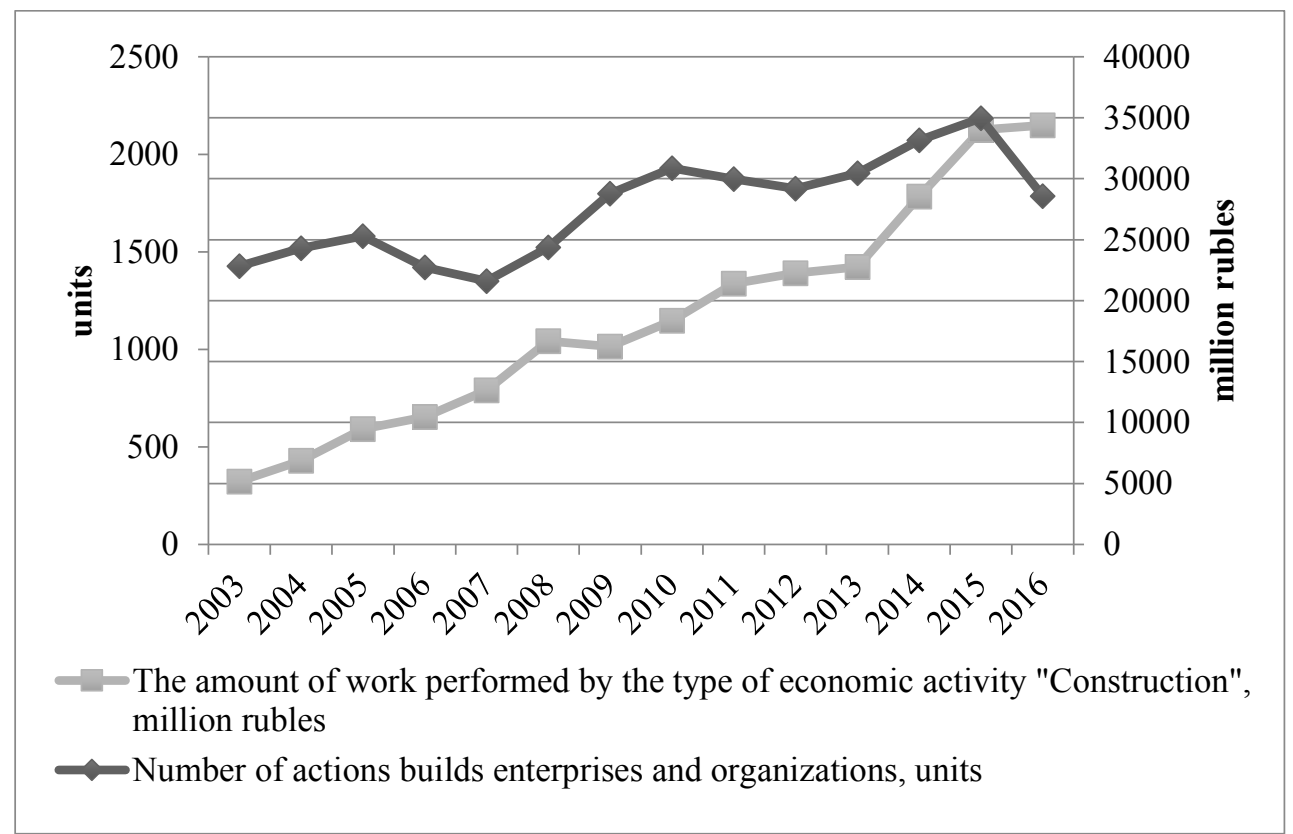

Fig. 1. The scope of work performed on the type of economic activity "Construction" (mln. Rub.); the number of existing construction organizations and enterprises in the Murmansk region (units), for 2003-2016.

The analysis of the data obtained shows that the growth in both the volume of construction work and the number of construction organizations and enterprises begins to accelerate in 2005 (see Fig. 1). This can be explained by the fact that during this period the primary 
residential construction market is recovering in the region and standard and mass housing are being established [16].

The graph obtained shows the regional construction market dependence on crises. When affected by crisis, enterprises prefer completing older projects rather than starting new ones until sales in the construction market recover. Each fluctuation on the graph (Fig. 1, the left scale of the diagram) is contingent on post-crisis recovery of the Murmansk region construction enterprises. Large enterprises remain on the market, occupying a large market share, performing the largest volume of construction work (Fig. 1, right scale of the diagram).

Analysing the Murmansk region labour force, more specifically the average annual number of people employed in different lines of business [15], one may conclude that only $5.2 \%$ of the labour force is employed in construction line of business (9th place among all business lines in the region).

On basis of the correlation analysis, a sufficiently strong correlation between the following indicators has been revealed: the number of buildings, units; total area of buildings, thousand $\mathrm{m}^{2}$. This correlation is demonstrated by means of the diagram (Fig. 2).

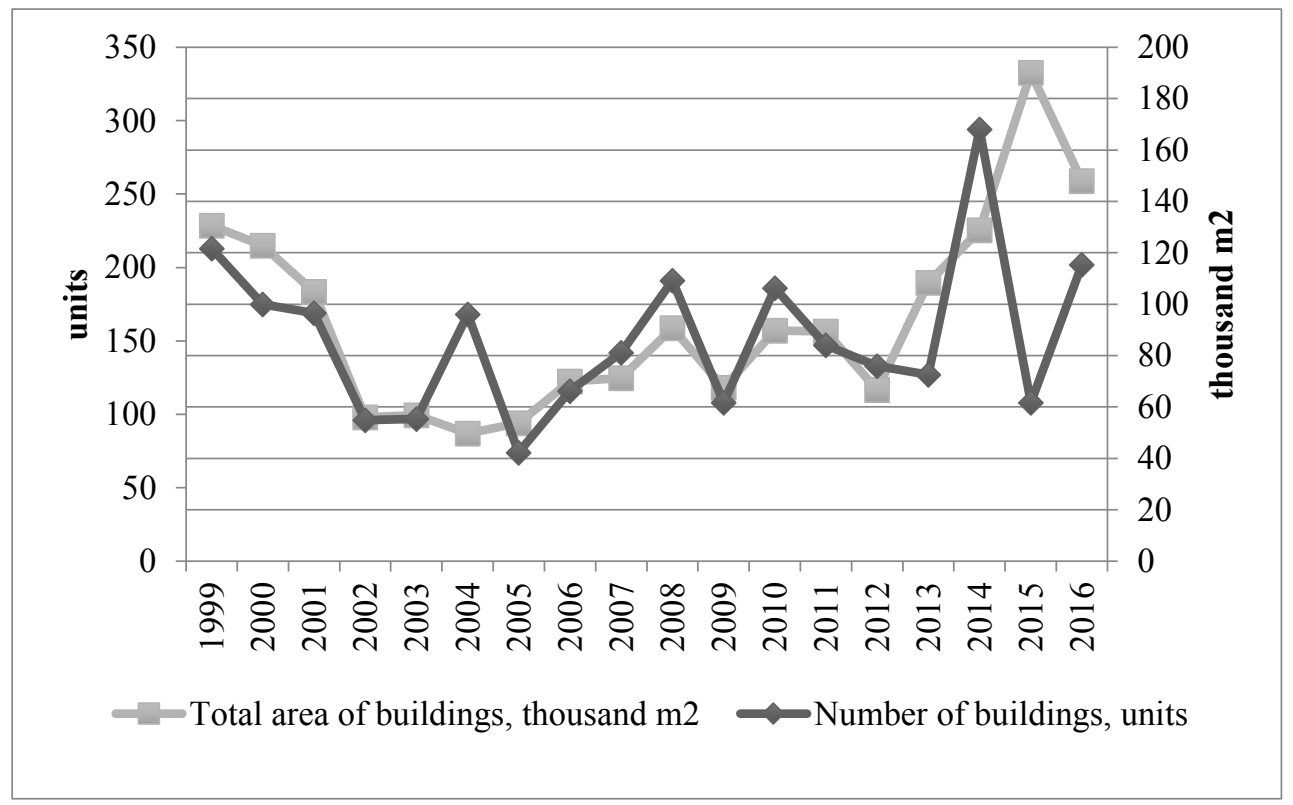

Fig. 2. Total area of buildings (thousand m2); number of buildings (units) for 1999-2016.

The figure above shows construction paces dynamic in the region with the post-crises periods standing out for there is a noticeable reduction in new construction in 2000-2003, 2005, 2009, and from 2016 up to the present time. In addition, until 2014, the number of buildings constructed was comparable to their area, but since 2015, there has been a sharp decrease in the number of buildings, whereas their area increases.

Assessing the development level of Murmansk region construction complex it should be noted that the region is short of new residential construction while the emphasis is placed on renovation and overhaul of buildings and structures built during the period from 1946 to 1995. [17]. Based on the data obtained from the Murmansk region Ministry of Construction and Territorial Development [18], at the present time, there are four construction organizations carrying cooperative housing projects in the region (Polyarnaya Zvezda OOO (OOO - a limited liability company under the laws of Russian Federation), Arkaim OOO, Murmanskpromstroy OAO (OAO - a public joint stock company under the laws of Russian Federation), SeverSitiPlyus OOO). However, there are only two new residential constructions 
being built with a completion deadline set in the 4th quarter of 2018. This problem is caused by a high migration flow to other regions [20], as new housing construction becomes economically inexpedient. Therefore, it is necessary to take measures to stimulate the sectorial economy, to attract third-party construction organizations from the nearest regions of the North-West Federal District, which will allow the organizations to expand the strategic economic zone and improve the situation in the new housing construction market in the region.

In accordance with the results of the Murmansk region construction industry analysis, the following measures can be proposed to ensure the balanced development of the regional construction complex:

1) Establishment of effective strategic development programs for the regional construction complex, which will help attract investment in the industry and stabilize the situation in the construction sector of the economy.

2) Establishment of an investment fund for socially significant objects construction.

3) Adopting a policy aimed at improving relations between all participants and stakeholders of the regional construction complex, namely, between: contractors and subcontractors, consumers and suppliers, investors.

4) Adoption of innovations in the regional construction complex to provide projects documentation digitalization and new construction technologies adoption for the construction work development.

5) Ensuring the growth of the regional construction complex resource efficiency by implementation of resource-efficient construction including passive and active-passive housing construction.

The measures suggested indicate the need to develop a strategic management system for the regional construction complex based on the RIC. In this regard, with the construction complex being the basis of the socio-economic development of the region, it is necessary to develop the RIC component "Industry and Entrepreneurship". The component should include all interrelated aspects of business environment development of the regional construction industry. This RIC component of a strategic chart should be developed in accordance with the following procedure: "target benchmark - sub-target - measurable indicator". In this regard, the following targets will be included in the "Industry and Entrepreneurship" component: 1) support for private investors and entrepreneurs; 2) development and implementation of the innovation component in the construction complex; 3) increase in resource efficiency in the construction sector of the region; 4) improvement of the regulatory framework in the field of construction. (tab. 1)

Table 1. The "Industry and Entrepreneurship" component of the strategic chart for the Murmansk region construction complex development.

\begin{tabular}{|c|c|}
\hline Target & Indicator \\
\hline & support for private investors and entrepreneurs \\
\hline \multirow{8}{*}{$\begin{array}{c}\text { Regional } \\
\text { construction activity } \\
\text { development }\end{array}$} & $\begin{array}{l}\text { The number of operating construction companies and organizations in } \\
\text { the region, units }\end{array}$ \\
\hline & $\begin{array}{l}\text { The scope of work performed in the "Construction' line of business, } \\
\text { mln. roubles / year. }\end{array}$ \\
\hline & $\begin{array}{c}\text { Number of employees operating in the "Construction' line of } \\
\text { business, \% of the total number of employees. }\end{array}$ \\
\hline & Construction organizations turnover, billion roubles / year. \\
\hline & Commissioning of residential and non-residential buildings, units \\
\hline & Total area of residential and non-residential buildings, thousand m2 \\
\hline & $\begin{array}{c}\begin{array}{c}\text { Public roads with hard surface density, km of tracks per } 1000 \mathrm{~km} 2 \text { of } \\
\text { territory. }\end{array}\end{array}$ \\
\hline & Railway tracks density, km of railways per $10,000 \mathrm{~km} 2$ of territory. \\
\hline
\end{tabular}




\begin{tabular}{|c|c|c|}
\hline $\begin{array}{l}\text { Investment } \\
\text { enhancing }\end{array}$ & \multicolumn{2}{|c|}{$\begin{array}{l}\text { Fixed capital expenditures in the "Construction" line of business, mln. } \\
\text { roubles / year. }\end{array}$} \\
\hline \multicolumn{3}{|c|}{ development and implementation of the innovation component in the construction complex } \\
\hline $\begin{array}{l}\text { Regional authorities } \\
\text { participation in } \\
\text { research and } \\
\text { development in the } \\
\text { construction } \\
\text { industry }\end{array}$ & \multicolumn{2}{|c|}{ Technological innovation costs, mln. roubles / year. } \\
\hline \multirow{4}{*}{$\begin{array}{l}\text { Research and } \\
\text { development of } \\
\text { construction } \\
\text { companies in the } \\
\text { region }\end{array}$} & \multicolumn{2}{|c|}{$\begin{array}{l}\text { Organizations that carried out research and development in the } \\
\text { "Construction" line of business, units }\end{array}$} \\
\hline & \multicolumn{2}{|c|}{$\begin{array}{l}\text { The number of personnel engaged in research and development in the } \\
\text { "Construction" line of business, people. }\end{array}$} \\
\hline & \multicolumn{2}{|c|}{$\begin{array}{l}\text { Internal current expenses for developments at enterprises in the } \\
\text { "Construction" line of business, mln. roubles / year. }\end{array}$} \\
\hline & \multicolumn{2}{|c|}{$\begin{array}{l}\text { The volume of innovative goods, works, services in the } \\
\text { "Construction" line of business, mln. roubles / year. }\end{array}$} \\
\hline $\begin{array}{l}\text { Construction } \\
\text { companies using } \\
\text { advanced } \\
\text { technology }\end{array}$ & \multicolumn{2}{|c|}{ The number of enterprises using BIM-technologies for design, units } \\
\hline \multirow{2}{*}{$\begin{array}{l}\text { Participation of } \\
\text { higher educational } \\
\text { institutions (HEIs) } \\
\text { in the innovative } \\
\text { development of the } \\
\text { building complex }\end{array}$} & \multicolumn{2}{|c|}{$\begin{array}{l}\text { The number of programs for engineering and construction specialties } \\
\text { in regional universities, units. }\end{array}$} \\
\hline & \multicolumn{2}{|c|}{$\begin{array}{c}\text { The number of universities in the region using BIM-technologies, } \\
\text { units }\end{array}$} \\
\hline \multicolumn{3}{|c|}{ increase in resource efficiency in the construction sector of the region } \\
\hline \multirow{4}{*}{$\begin{array}{l}\text { State regulation of } \\
\text { construction } \\
\text { resource efficiency } \\
\text { in the region as a } \\
\text { basis for } \\
\text { environmental } \\
\text { protection }\end{array}$} & \multicolumn{2}{|c|}{$\begin{array}{c}\text { Production index in the "Production and distribution of electricity, gas } \\
\text { and water" business line, } \% \text { over a prev. year }\end{array}$} \\
\hline & \multicolumn{2}{|c|}{ Fresh water usage, $\mathrm{mln} . \mathrm{m} 3 /$ year. } \\
\hline & \multicolumn{2}{|c|}{$\begin{array}{l}\text { Discharge of polluted wastewater to surface water bodies, million m3 } \\
\qquad / \text { year. }\end{array}$} \\
\hline & \multicolumn{2}{|c|}{ Air pollutant emissions from stationary sources, thousand tons / year. } \\
\hline \multirow{3}{*}{$\begin{array}{l}\text { The use of resource- } \\
\text { efficient } \\
\text { technologies in } \\
\text { construction by } \\
\text { construction } \\
\text { enterprises }\end{array}$} & \multicolumn{2}{|c|}{$\begin{array}{c}\text { Construction enterprises and organizations engaged in energy- } \\
\text { efficient construction, units }\end{array}$} \\
\hline & \multicolumn{2}{|c|}{ The number of built passive houses, units / year. } \\
\hline & \multicolumn{2}{|c|}{ The number of built active-passive houses, units / year. } \\
\hline \multicolumn{3}{|c|}{ improvement of the regulatory framework in the field of construction } \\
\hline \multirow{2}{*}{\multicolumn{2}{|c|}{$\begin{array}{l}\text { Conducting programs aimed at supporting small } \\
\text { entrepreneurs and individual entrepreneurs of the } \\
\text { Arctic regions whose activities are related to the } \\
\text { "Construction" industry }\end{array}$}} & $\begin{array}{c}\text { The number of programs implemented, } \\
\text { units }\end{array}$ \\
\hline & & $\begin{array}{l}\text { The number of new programs ready for } \\
\text { implementation, units }\end{array}$ \\
\hline \multirow{2}{*}{\multicolumn{2}{|c|}{$\begin{array}{l}\text { Conducting programs aimed at attracting investors } \\
\text { for the development of the Arctic region } \\
\text { construction complex }\end{array}$}} & $\begin{array}{c}\text { The number of programs implemented, } \\
\text { units }\end{array}$ \\
\hline & & $\begin{array}{l}\text { The number of new programs ready for } \\
\text { implementation, units }\end{array}$ \\
\hline
\end{tabular}

The indicators proposed in the table 1 are based on state statistical data and the new indicators suggested in the paper. Collecting data on these indicators in essential for high quality long-term planning and forecasting the industry development. 


\section{Conclusions}

The analysis of the Murmansk region construction organizations and enterprises revealed the regional construction market dependence on crises, which should be taken into account when developing a strategic management system. In addition, the analysis of the Murmansk regional construction complex business environment allowed us to identify a list of relevant activities that should be included in the system of regional management.

The component "Industry and Entrepreneurship" developed within the framework of RIC will allow monitoring indicators reflecting the degree of achievement the targets set, identifying deviations, and managing changes with the aim of balanced development of the Murmansk region construction complex.

\section{References}

1. Strategy of development of the Arctic zone of the Russian Federation and national security for the period up to 2020

2. The decree of the President of the Russian Federation" about the land territories of the Arctic zone of the Russian Federation " of 02.05.2014, N 296

3. URL : http://www.morskayakollegiya.ru/primorskie_regio/atlnant/

4. N.Y. Sorokina, Siberian Socium, Vul 2-1, 8-19 (2018)

5. P. T. Skuf'ina, E. E. Toropchina, S. V. Baranov, Apatity, KSC RAS, 124 (2017)

6. O.V. Cygankova, O.V. Romanchenko, O.L. Shemetkova, Regional Economics and management: electronic scientific journal 4(48), 181-193 (2016)

7. V.L. Baburin, S.P. Zemcov, Regional studies 4(50), 76-83 (2015)

8. M.I. Kameneckij, Scientific works: Institute of national economic forecasting of RAS 13, 402-417 (2015)

9. T.R. Alekseeva, Vestnik MGSU 3, 236-246 (2014)

10. S.B. Pozmogova, Vestnik SGSEU 2, 112-115 (2011)

11. L.S. Belousova, News of southwest state University, Series: Economy. Sociology. Management 2, 55-62 (2011)

12. S.V. Miroshnichenko, Proceedings of higher educational institutions, Construction 1112, 38-44 (2006)

13. Strategy of socio-economic development of the Murmansk region until 2020 and for the period up to 2025, https://minec.gov-murman.ru/activities/strat_plan/sub02/

14. A. Kozlov, S. Gutman, I. Zaychenko, et.al., IOP Conf. Series: 91(1), 012073 (2015)

15. URL : https://nangs.org/analytics/rosstat-regiony-rossii-osnovnye-kharakteristiki-subektov-rossijskoj-federatsii-2016-pdf

16. T.P. Cheremisina, World of Economics and management 17-3, 100-111 (2017)

17. E.K. Tereshko, Youth scientific Bulletin 6(31), 134-144 (2018)

18. URL : http://minstroy.gov-murman.ru

19. V.V. Fauser, Bulletin of Syktyvkar state University 1, 129-144 (2015) 